LOPES, JC; FREITAS, AR; CANDIDO, AO; VENANCIO, LP; FÁVARIS, NAB. 2018. Physiological quality of scarlet eggplant seeds produced in soil contaminated with industrial residues. Horticultura Brasileira 36: 066-072. DOI - http://dx.doi.org/10.1590/S0102-053620180111

\title{
Physiological quality of scarlet eggplant seeds produced in soil contaminated with industrial residues
}

\author{
José Carlos Lopes ${ }^{1}$; Allan R Freitas'; Amarilson O Candido²; Luan PVenancio²; Nathália Aparecida B Fávaris ${ }^{1}$ \\ ${ }^{1}$ Universidade Federal do Espírito Santo (UFES), Alegre-ES, Brazil; jcufes@bol.com.br; allanrochaf@gmail.com; nath-braganca@hotmail. \\ com; ${ }^{2}$ Universidade Federal de Viçosa (UFV), Viçosa-MG, Brazil; amarilsonoc@hotmail.com; lpagronomo1990@gmail.com
}

\begin{abstract}
Industrial and organic residues cause environmental impacts at various levels. However, these residues present potential to correct soil acidity and fertility. Considering the possibility of using these alternative sources, the objective of this study was to analyze the quality of scarlet eggplant seeds produced with the use of industrial waste. The experiment was carried out in a greenhouse. We used scarlet eggplant seeds (Solanum gilo), cv. 'Verde-Claro', and the soil was Typic Hapludox. The experimental design was randomized blocks, in a factorial distribution $(3 \times 4 \times 5)$, being three soil variations [(pure soil (S), soil + cattle manure (SE) and, soil + sewage sludge (SL)], four corrective treatments [without correction (C1), limestone (C2), steel slag (C3) and marble powder (C4)], and five periods of seed storage $(0,100,120,140$ and 160 days). The use of steel slag and marble powder associated with the addition of sewage sludge and cattle manure increased fresh mass of plants, at $40 \%$, and dry mass of plants, at $48 \%$, when compared with the pure soil. After 140 day of storage, negatives effects on the vigor of scarlet eggplant seeds could be noticed.
\end{abstract}

Keywords: Solanum gilo, storage, biosolids, soil correction, nutrition.

\section{RESUMO}

Qualidade fisiológica de sementes de jiló produzidas em solo com resíduos industriais

Os resíduos industriais e orgânicos causam impactos ambientais em diversos níveis. No entanto, apresentam potencial para a correção da acidez e a fertilização do solo. A partir da possibilidade de utilização destas fontes alternativas, objetivou-se analisar a qualidade de sementes de jiló produzidas com o uso de resíduos industriais. $\mathrm{O}$ experimento foi desenvolvido em casa de vegetação sendo utilizadas sementes de jiló (Solanum gilo), cv. 'Verde-Claro'. O solo utilizado é um Latossolo Vermelho-Amarelo distrófico. O delineamento experimental utilizado foi em blocos casualizados, com distribuição fatorial $(3 \times 4 \times 5)$, sendo três variações de solo [solo puro $(\mathrm{S})$, solo + esterco bovino (SE) e solo + lodo de esgoto (SL)], quatro tratamentos corretivos [sem correção $(\mathrm{C} 1)$, calcário $(\mathrm{C} 2)$, escória de siderurgia (C3) e pó de mármore (C4)], e cinco períodos de armazenamento das sementes $(0,100,120,140$ e 160 dias). O uso de escória de siderúrgica e pó de mármore associados à adição de lodo de esgoto e esterco bovino aumentou as massas fresca das plantas, em $40 \%$, e seca, em 48\%, quando comparadas com o solo puro. Após 140 dias de armazenamento há efeitos negativos no vigor das sementes de jiló.

Palavras-chave: Solanum gilo, armazenamento, biossólido, corretivo, nutrição.

\section{Received on July 4, 2016; accepted on August 3, 2017}

$S^{\prime}$ Tolanum gilo is one species of Solanaceae family, probably originated from Africa, introduced in Brazil by slaves. The fruit, the scarlet eggplant, has great acceptance in the Southeastearn part of Brazil, considering the States of Rio de Janeiro and Minas Gerais the main producers, with average productivities ranging from 20 to 60 $\mathrm{t} \mathrm{ha}^{-1}$. The fruits have bitter taste, are sources of carbohydrates, proteins, fat, phosphorus, calcium, iron, vitamins A, B and C. Scarlet eggplant is quite demanding in relation to temperature and under appropriated conditions harvest begins between 80 and 100 days after sowing, extending for more than 100 days (Filgueira, 2013). Seed quality is considered one of the main factors to be analyzed in a production system. However, the seed production process varies according to the species. Production of quality seeds depends on numerous cares as the place of origin, highlighting soil nutrient availability, since it directly influences on formation of the embryo, the genetics and chemical composition of the species (Carvalho \& Nakagawa, 2012). Several studies on nutritional management of the "motherplant" indicate that many factors may compromise the physiological quality of the seeds as for example the stage of translocation of nutrients to the seeds and the seed storage after its physiological maturation; these factors are considered as mandatory steps in a seed production program (Silva et al., 2015).

Souza et al. (2014) state that, during the storage time, the reduction of viability of seed germination is represented by a sigmoid negative curve, being variable to the conditions of temperature and local humidity. From the reduction in the respiratory rate, orthodox seed storage with lower water content allows the viability of biological materials for a longer period (Nascimento 2009). As the seeds of P. angulata, solanaceae, are orthodox, they did not present any reduction in germination and vigor during storage for up to 45 days (Carvalho et al., 2014). 
Lima \& Smiderle (2014) reported that the seeds of chilli pepper "Malagueta" (Capsicum frutencens) kept high germination until 90 -day storage, stored at temperature of $25^{\circ} \mathrm{C}$.

In nutritional management, among the several factors involved, fertilization and correction of soil acidity are of great importance. Organic nutrient sources and cattle and poultry manures, as well as others, still need to have their benefits known considering seed quality, such as sewage sludge. However, environmental practices aiming to use residues such as steel slag and marble powder, for correcting soil acidity, and sewage sludge, as nutrient source for plants, have been studied in the latest years in order to reduce the impact of their deposition and to reduce production costs (Grotto et al., 2013; Freitas et al., 2015).

The aim of this work was to analyze the scarlet eggplant seed quality produced in substrates containing industrial and organic residues and stored at room and controlled temperature.

\section{MATERIAL AND METHODS}

The experiment was carried out in a greenhouse at Campus of Centro de Ciências Agrárias da Universidade Federal do Espírito Santo, located in the municipality of Alegre-ES $\left(20^{\circ} 45^{\prime} 48^{\prime}\right.$ 'S; $41^{\circ} 31^{\prime} 57^{\prime \prime} \mathrm{W} ; 250 \mathrm{~m}$ altitude). The climate of the region is hot and humid in the summer, with dry winter, and the average annual rainfall is $1,200 \mathrm{~mm}$. The average annual air temperature is around $27^{\circ} \mathrm{C}$ (Inmet, 2015).

The authors used scarlet eggplant seeds (Solanum gilo), cv. 'Verde-Claro', from Fazenda Feliz Lembrança, located in the municipality of Alegre. The used soil was Typic Hapludox collected to a depth of 15-60 cm layer, air-dried. The soil clods were manually broken and passed through a $2.00 \mathrm{~mm}$ sieve in order to obtain TFSA (thin air dried soil). Physical and chemical analyses, as well as analyses of the sewage sludge and the cattle manure were performed (Table 1). The sewage sludge was collected near the anaerobic lagoon of the Sewage Treatment Station of the
Espírito Santense Sanitation Company, in Valparaíso, municipality of Serra-ES, and the cattle manure, was collected at the garden of Instituto Federal de Educação do Espírito Santo, Campus Alegre.

As soil correctives, the authors used limestone, steel slag and marble powder from marble factory of the South part of Espírito Santo, homogenized in a 60 mesh sieve $(250 \mu \mathrm{m})$ for analyses (Table 2).

The soil was treated with correctives, using a dose based on the method of base saturation (V) at 80\% (Prezotti et al., 2007), put in plastic bags and incubated during 21 days, the moisture was maintained at $60 \%$ of total pore volume, according to Freire et al. (1980). In the treatments using marble powder, we applied gypsum in order to achieve "three parts of calcium and one part of magnesium" ratio, making calcium/magnesium ratio, contained in limestone and steel slag, similar.

After incubation time, the treated soils were dried in the shade and homogenized by sieving through a 2 $\mathrm{mm}$ mesh sieve, for basic fertilization with phosphorus and potassium at a dose of 90 and $78 \mathrm{~kg} \mathrm{ha}^{-1}$, respectively, for all treatments. The sewage sludge and cattle manure were applied at a dose of $80 \mathrm{tha}^{-1}$, according to the respective treatments and incubated for 20 days. Then, samples of treated soils were sieved through a $2 \mathrm{~mm}$ mesh sieve and put in $5-\mathrm{dm}^{3}$ pots. Twenty five seeds were sown per pot, kept in a greenhouse covered with black polyolefin screens with 50\% light retention.

Soil moisture during the experiment was maintained at around $70 \%$ of field capacity (Filgueira, 2013) weighing the pots daily, using an analytical scale $(0.001 \mathrm{~g})$. Field capacity (CC) was determined using Richards extractor (tension of $10 \mathrm{kPa}$ ).

Twenty days after sowing, first thinning was done, leaving three plants per pot. Then, the authors determined emergence $(\%)$ and emergence speed index (IVE), according to Maguire (1962), fresh and dry mass of the aboveground part (mg per plant) of the plants. Ten days after the first thinning, the second thinning was done, leaving one plant per pot, remaining there until fruit production (140 days).

Fruits were harvested when showed yellow-orange peel coloration. The seeds were extracted manually, washed in running water and placed to dry in the shade on paper towel for 72 hours; when water content reached $8 \%$, the seeds were put in plastic bags and stored in a cold chamber $\left(8 \pm 2^{\circ} \mathrm{C}\right.$ and RU of $\left.60 \%\right)$.

The seed were evaluated during five storage times, considering that the first evaluation was done before storage and the others after 100, 120, 140 and 160 days after storage. In each evaluation, the authors considered: water content, using three sub-samples of 25 seeds, using the oven method at $105 \pm 3^{\circ} \mathrm{C}$, during 24 hours (Brasil, 2009) being the results expressed in percentage. The germination of normal seedlings was obtained using four subsamples of 25 seeds for each treatment, sown in Petri dishes lined with two sheets of germitest paper, moistened with distilled water in the proportion equivalent to 2.5 times the dry paper mass, kept in a germination chamber (BOD type), regulated at alternate temperature ranging from $20-30^{\circ} \mathrm{C}$ and 8 $\mathrm{h}$ photofase. The speed of germination was determined at the germination test, considering germinated seed those ones which presented protrusion of the primary root $\geq 2.00 \mathrm{~mm}$ (Maguire, 1962). Fresh and dry masses of the plants were put in Kraft paper bags; after, fresh mass was obtained and kept in a forced air circulation greenhouse, at $72^{\circ} \mathrm{C}$, during 72 hours. The masses were determined in an analytical scale $(0.0001 \mathrm{~g})$, and the results expressed in mg per seedling.

The experimental design was randomized blocks, in a factorial distribution $(3 \times 4 \times 5)$, being three types of soil [pure soil (S), soil + cattle manure (SE) and, soil + sewage sludge (SL)], four corrective treatments [without correction (C1), limestone (C2), steel slag (C3) and marble powder (C4)], and five storage times $(0,100,120,140$ and 160 days), in a split-plot, with four replicates of 25 seeds.

The data related to these evaluated traits were transformed, as following: 
emergence $\mathrm{Y}=\left[\arcsin (\mathrm{x} / 100)^{1 / 2}\right]$ and others, using $\left[(\mathrm{x}+0.5)^{1 / 2}\right]$. After transformed, the data were submitted to analysis of variance, if any significant difference was found, the averages were compared using Tukey test, at 5\% probability, and regression analysis.

\section{RESULTS AND DISCUSSION}

All heavy metals in the sewage sludge showed amounts below the maximum limits determined by CONAMA Resolution (2006). The soil used was characterized by the low nutrient availability and high acidity. Except for $\mathrm{Ca}, \mathrm{Cu}$ and $\mathrm{Zn}$, the cattle manure showed higher values for all macronutrients and micronutrients (Table 1). The cattle manure provided organic nitrogen accumulation, an increase in mineralization potential and nutrient availability when compared with other organic fertilizers able to promote an improvement of soil chemical properties and an increase in $\mathrm{P}, \mathrm{N}$ and $\mathrm{Mg}$ contents (Oliveira et al., 2014).

Among these correctives, steel slag stood out showing the highest averages of calcium oxide, neutralizing power and relative efficiency (Table 2). These variables show the neutralizing power of soil acidity (Embrapa, 2004), which can increase nutrient availability to the plants.

Considering the percentage of emergency and speed of seedling emergence in the pots, the authors verified no difference among the soil correctives. However, the highest emergence averages were found with the use of the steel slag and marble

Table 1. Chemical characterization of the substrates. Alegre, UFES, 2016.

\begin{tabular}{|c|c|c|c|c|c|c|c|}
\hline \multirow{2}{*}{ Substrate } & $\mathbf{N}$ & $\mathbf{P}$ & $\mathbf{C a}$ & Mg & $\mathrm{Cu}$ & $\mathrm{Cr}$ & Zn \\
\hline & \multicolumn{7}{|c|}{$\left(\mathrm{mg} \mathrm{dm}^{-3}\right)$} \\
\hline Soil & - & 5.0 & 0.52 & 0.02 & - & - & - \\
\hline Sewage sludge & 21560.0 & 856.2 & 6275.6 & 291.6 & 571.5 & 568.7 & 1010.9 \\
\hline Manure & 29400.0 & 12500.0 & 2820.0 & 1230.0 & 235.0 & - & 930.0 \\
\hline \multirow{2}{*}{ Substrate } & Co & $\mathbf{N i}$ & Cd & $\mathbf{P b}$ & $\mathrm{Hg}$ & Mn & $\mathrm{Fe}$ \\
\hline & \multicolumn{7}{|c|}{$\left(\mathrm{mg} \mathrm{dm}^{-3}\right)$} \\
\hline Soil & - & - & - & - & - & - & - \\
\hline Sewage sludge & 8.0 & 25.0 & 3.0 & 80.0 & 1.5 & 118.0 & 34.0 \\
\hline Manure & - & - & - & - & & 745.0 & 4110.0 \\
\hline \multirow{2}{*}{ Substrate } & B & $\mathbf{K}$ & $\mathbf{S}$ & Al & \multirow{2}{*}{$\begin{array}{c}\mathrm{pH} \\
\left(\mathbf{H}_{2} \mathrm{O}\right)\end{array}$} & \multirow{2}{*}{ SB (\%) } & \multirow[b]{2}{*}{ - } \\
\hline & & $(\mathrm{mg}$ & $\left.\mathrm{m}^{-3}\right)$ & & & & \\
\hline$\overline{\text { Soil }}$ & - & - & - & 0.16 & 4.6 & 33.4 & - \\
\hline Sewage sludge & 3.5 & 7342.6 & 2.9 & - & 6.3 & - & - \\
\hline Manure & 24.6 & 24800.0 & 3.5 & - & 7.1 & - & - \\
\hline
\end{tabular}

$\overline{\mathrm{SB}}=$ base saturation.

Table 2. Chemical composition of limestone, steel slag and marble powder. Alegre, UFES, 2016.

\begin{tabular}{lccc}
\hline Variables & Limestone & Steel slag & Marble powder \\
\hline Calcium oxide (\%) & 31.4 & 37.0 & 26.8 \\
Silicon dioxide (\%) & - & 21.3 & - \\
${ }^{1}$ Neutralizing power & 82.5 & 97.5 & 95.7 \\
2Relative efficiency (\%) & 100.0 & 100.0 & 97.8 \\
${ }^{3}$ PRNT (\%) & 82.5 & 97.5 & 93.6 \\
\hline
\end{tabular}

${ }^{1}$ Neutralizing power $=\% \mathrm{CaO} \times 1.79+\% \mathrm{MgO} \times 2.48 ;{ }^{2}$ Relative efficiency $=[(\mathrm{A} \times 0.0)+(\mathrm{B} \times$ $0.2)+(\mathrm{C} \times 0.6)+(\mathrm{D} \times 1.0) / 100]$, in which $\mathrm{A}, \mathrm{B}, \mathrm{C}=\%$ of the corrective which is retained, respectively, on the sieves numbers 10,20 and 50 , and $\mathrm{D}=\%$ of the corrective which passes through sieve number 50. ${ }^{3}$ Reaction power and total neutralization (PRNT): (PN x ER)/ 100. powder. The addition of organic matter influenced negatively the emergence percentage and speed, mainly when using cattle manure (Table 3 ). This fact was observed in other studies in which the seedling emergence was lower in the presence of organic acids in soil. This behavior might be associated with phytotoxicity determined by carbon chain of the acids (Tunes et al., 2013).

The greatest production of fresh and dry masses was observed in plants grown with the use of steel slag and marble powder associated with the addition of sewage sludge and cattle manure, which presented similar results (Table 3), in 40\%, fresh mass, and in $48 \%$, dry mass, when compared with pure soil suggesting that these correctives were efficient to neutralize exchangeable acidity (Al) and correct $\mathrm{pH}$, favoring seedling growth. Some rocks present chemical potentials which are able to enrich soils with calcium and magnesium, promoting an increase in $\mathrm{pH}$ of the soil and availability of phosphorus and molybdenum for plant growth (Nogueira et al., 2013). With the addition of organic matter and sewage sludge, some studies reported benefits related to an increase in amount of humus, cation exchange capacity, improvement in soil water infiltration and storage capacity, reduction of erosion and an increase in resistance of aggregates, and benefits to development and initial growth of plants, with greater production of dry mass and fruits (Caldeira et al., 2013; Freitas et al., 2015).

Except for soil treated with marble powder, the authors did not notice fruit production when plants were grown without the addition of organic matter. The absence of fruits was also verified in soil without correction and fertilized with sewage sludge (Table 4 ), corroborating the results obtained by Freitas et al. (2015).

Considering the storage time of the produced seeds, the authors observed that the water contents between seed lots did not show any differences, remaining close to $8 \%$, presenting minimum of 7.53 and maximum of 8.29 (Table 4), which are inferior to maximum amplitude of 1 to 2 percentage points, which is 
Table 3. Emergency (E) speed emergency index (IVE) of the seedlings, fresh mass (MF) and dry mass (MS) of the seedling aboveground part in soil with correctives and organic matter sources. Alegre, UFES, 2016.

\begin{tabular}{|c|c|c|c|c|c|c|}
\hline \multirow{3}{*}{ CR } & \multicolumn{6}{|c|}{ Organic matter } \\
\hline & $\mathbf{S}^{5}$ & $\mathrm{SL}^{6}$ & $\mathbf{S E}^{7}$ & $S^{5}$ & $\mathbf{S L}^{6}$ & $\mathbf{S E}^{7}$ \\
\hline & \multicolumn{3}{|c|}{$[\mathrm{E}(\%)]$} & \multicolumn{3}{|c|}{ (IVE) } \\
\hline $\mathrm{C} 1^{1}$ & $94.0 \mathrm{Aa}$ & $88.0 \mathrm{ABa}$ & $80.0 \mathrm{Ba}$ & $4.0 \mathrm{Aa}$ & $3.7 \mathrm{Aa}$ & $3.3 \mathrm{Aa}$ \\
\hline $\mathrm{C} 2^{2}$ & $91.0 \mathrm{Aa}$ & $88.0 \mathrm{Aa}$ & $80.0 \mathrm{Ba}$ & $3.9 \mathrm{Aa}$ & $3.8 \mathrm{Aa}$ & $2.9 \mathrm{Ba}$ \\
\hline $\mathrm{C} 3^{3}$ & $95.0 \mathrm{Aa}$ & $91.0 \mathrm{Aa}$ & $84.0 \mathrm{Ba}$ & $4.2 \mathrm{Aa}$ & 4.0 Aa & $3.4 \mathrm{Ba}$ \\
\hline \multirow[t]{2}{*}{$\mathrm{C} 4^{4}$} & $96.0 \mathrm{Aa}$ & $88.0 \mathrm{ABa}$ & $84.0 \mathrm{Ba}$ & 4.1 Aa & $3.9 \mathrm{Aa}$ & $3.5 \mathrm{Ba}$ \\
\hline & \multicolumn{3}{|c|}{ [MF (mg/seedling)] } & \multicolumn{3}{|c|}{ [MS (mg/seedling)] } \\
\hline $\mathrm{C} 1^{1}$ & $113.6 \mathrm{Cb}$ & $351.5 \mathrm{Bc}$ & $1192.0 \mathrm{Ab}$ & $18.3 \mathrm{Cc}$ & $47.8 \mathrm{Bc}$ & $102.3 \mathrm{Ac}$ \\
\hline $\mathrm{C} 2^{2}$ & $456.1 \mathrm{Ba}$ & $872.6 \mathrm{Bb}$ & $1141.2 \mathrm{Ab}$ & $57.6 \mathrm{Bb}$ & $83.2 \mathrm{Bb}$ & $148.1 \mathrm{Ab}$ \\
\hline $\mathrm{C} 3^{3}$ & $538.6 \mathrm{Ba}$ & 1173.1 Aa & 1606.7 Aa & $80.6 \mathrm{Ba}$ & $151.4 \mathrm{Aa}$ & $185.8 \mathrm{Aa}$ \\
\hline $\mathrm{C} 4^{4}$ & $558.2 \mathrm{Ba}$ & $1265.6 \mathrm{Aa}$ & $1401.1 \mathrm{Aa}$ & $74.1 \mathrm{Ba}$ & $132.1 \mathrm{Aa}$ & $176.2 \mathrm{Aa}$ \\
\hline
\end{tabular}

Averages followed by the same letter, lowercase in the column and uppercase in the lines did not differ significantly from each other, Tukey, $\mathrm{p}<0.05$. ${ }^{1}$ Without Correction; ${ }^{2}$ Limestone; ${ }^{3}$ Steel slag; ${ }^{4}$ Marble powder; ${ }^{5}$ Pure soil; ${ }^{6}$ Soil + Sewage sludge; ${ }^{7}$ Soil + Cattle manure.

Table 4. Water content (\%) of scarlet eggplant seeds evaluated after storage periods in cold chamber. Alegre, UFES, 2016.

\begin{tabular}{|c|c|c|c|c|c|c|}
\hline \multirow{2}{*}{\multicolumn{2}{|c|}{ Treatments }} & \multicolumn{5}{|c|}{ Period (days) } \\
\hline & & \multirow{2}{*}{$\begin{array}{c}\mathbf{0} \\
0.00^{*}\end{array}$} & \multirow{2}{*}{$\begin{array}{c}\mathbf{1 0 0} \\
0.00^{*}\end{array}$} & \multirow{2}{*}{$\frac{120}{0.00^{*}}$} & \multirow{2}{*}{$\begin{array}{l}\mathbf{1 4 0} \\
0.00^{*}\end{array}$} & \multirow{2}{*}{$\frac{160}{0.00^{*}}$} \\
\hline $\mathrm{C} 1^{1}$ & $\mathrm{~S}^{5}$ & & & & & \\
\hline $\mathrm{C} 1^{1}$ & $\mathrm{SL}^{6}$ & $0.00^{*}$ & $0.00^{*}$ & $0.00^{*}$ & $0.00^{*}$ & $0.00^{*}$ \\
\hline $\mathrm{C} 1^{1}$ & $\mathrm{SE}^{7}$ & $8.03 \mathrm{a}$ & $7.69 \mathrm{a}$ & $7.88 \mathrm{a}$ & $8.05 \mathrm{a}$ & $8.14 \mathrm{a}$ \\
\hline $\mathrm{C} 2^{2}$ & $\mathrm{~S}^{5}$ & $0.00^{*}$ & $0.00^{*}$ & $0.00^{*}$ & $0.00^{*}$ & $0.00^{*}$ \\
\hline $\mathrm{C} 2^{2}$ & $\mathrm{SL}^{6}$ & $8.26 \mathrm{a}$ & $8.17 \mathrm{a}$ & $7.98 \mathrm{a}$ & $8.12 \mathrm{a}$ & $8.04 \mathrm{a}$ \\
\hline $\mathrm{C} 2^{2}$ & $\mathrm{SE}^{7}$ & $7.98 \mathrm{a}$ & $7.87 \mathrm{a}$ & $8.20 \mathrm{a}$ & $8.05 \mathrm{a}$ & $8.19 \mathrm{a}$ \\
\hline $\mathrm{C} 3^{3}$ & $\mathrm{~S}^{5}$ & $0.00^{*}$ & $0.00^{*}$ & $0.00^{*}$ & $0.00^{*}$ & $0.00^{*}$ \\
\hline $\mathrm{C} 3^{3}$ & $\mathrm{SL}^{6}$ & $8.11 \mathrm{a}$ & $8.01 \mathrm{a}$ & $8.19 \mathrm{a}$ & $8.06 \mathrm{a}$ & $7.89 \mathrm{a}$ \\
\hline $\mathrm{C} 3^{3}$ & $\mathrm{SE}^{7}$ & $7.60 \mathrm{a}$ & $7.73 \mathrm{a}$ & $7.75 \mathrm{a}$ & $7.53 \mathrm{a}$ & $7.81 \mathrm{a}$ \\
\hline $\mathrm{C} 4^{4}$ & $\mathrm{~S}^{5}$ & $7.83 \mathrm{a}$ & $8.05 \mathrm{a}$ & $7.90 \mathrm{a}$ & $8.11 \mathrm{a}$ & $8.07 \mathrm{a}$ \\
\hline $\mathrm{C} 4^{4}$ & $\mathrm{SL}^{6}$ & $7.99 \mathrm{a}$ & $8.13 \mathrm{a}$ & $8.16 \mathrm{a}$ & $8.04 \mathrm{a}$ & $7.87 \mathrm{a}$ \\
\hline $\mathrm{C} 4^{4}$ & $\mathrm{SE}^{7}$ & $8.21 \mathrm{a}$ & $8.29 \mathrm{a}$ & $8.15 \mathrm{a}$ & $8.10 \mathrm{a}$ & $8.07 \mathrm{a}$ \\
\hline
\end{tabular}

Averages followed by the same letter in the line did not differ significantly from each other, Tukey, $\mathrm{p}<0.05$. ${ }^{1}$ Without correction; ${ }^{2}$ Limestone; ${ }^{3}$ Steel slag; ${ }^{4}$ Marble powder; ${ }^{5}$ Pure soil; ${ }^{6}$ Soil + Sewage sludge; ${ }^{7}$ Soil + Cattle manure. *No fruit production was observed.

accepted to ensure the credibility of the results obtained in vigor tests (Marcos Filho, 1999).

The germination of the seeds produced in soil corrected with limestone and enriched with sewage sludge presented the lowest averages in relation to the ones produced in soil enriched with manure, reaching $15 \%$ of germination in soil fertilized with sewage sludge and $73 \%$ in soil fertilized with cattle manure (figure $1 \mathrm{~B}$ and $\mathrm{C}$ ). The average germination of seeds produced in soil corrected with steel slag and marble powder associated with organic matter was above $96 \%$ with values up to $100 \%$. This fact was not observed when the authors used the conventional soil corrective, limestone, with averages of approximately $60 \%$ (Figure 1B and C).

The addition of marble waste and steel slag may have increased exchangeable calcium and magnesium contents in the soil, increasing the cation exchange and providing more nutrients, as it was observed by Machado et al. (2010). The use of rock wastes promoted positive effect on the chemical quality of degraded soils, which reflects on the development of the cultivated species (Silva et al., 2008). The fertilizer effect on the seed quality can be associated with available nutrients, which perform an important role in plant metabolism and help synthesize and accumulate carbohydrates (Taiz \& Zeiger, 2013).

Storage time did not influence on seed germination, except for the seeds from plants produced in soil amended with limestone and fertilized with sewage sludge, which germination began after 120 days of storage and finished after 140 days of storage (Figure 1B). During seed formation, intense cell divisions and expansions, followed by progressive increase of dry mass, occur due to the synthesis and deposition of reserves. Then, seeds interrupt the physiological flow with the mother plant, becoming independent individuals (Marcos Filho, 2005; Bewley et al., 2013). Leprince \& Buitink (2010) stated that the seeds go into a dormancy phase under a range of environmental conditions. Thus, the variations in environmental conditions, in which the seeds were submitted during the processes of maturation and storage, may interfere directly in physiological quality causing metabolic degenerative changes, such as delay in germination, leaching of solutes and changes in enzymatic activity (Hehenberger et al., 2012).

The germination behavior during storage is related to sources of 


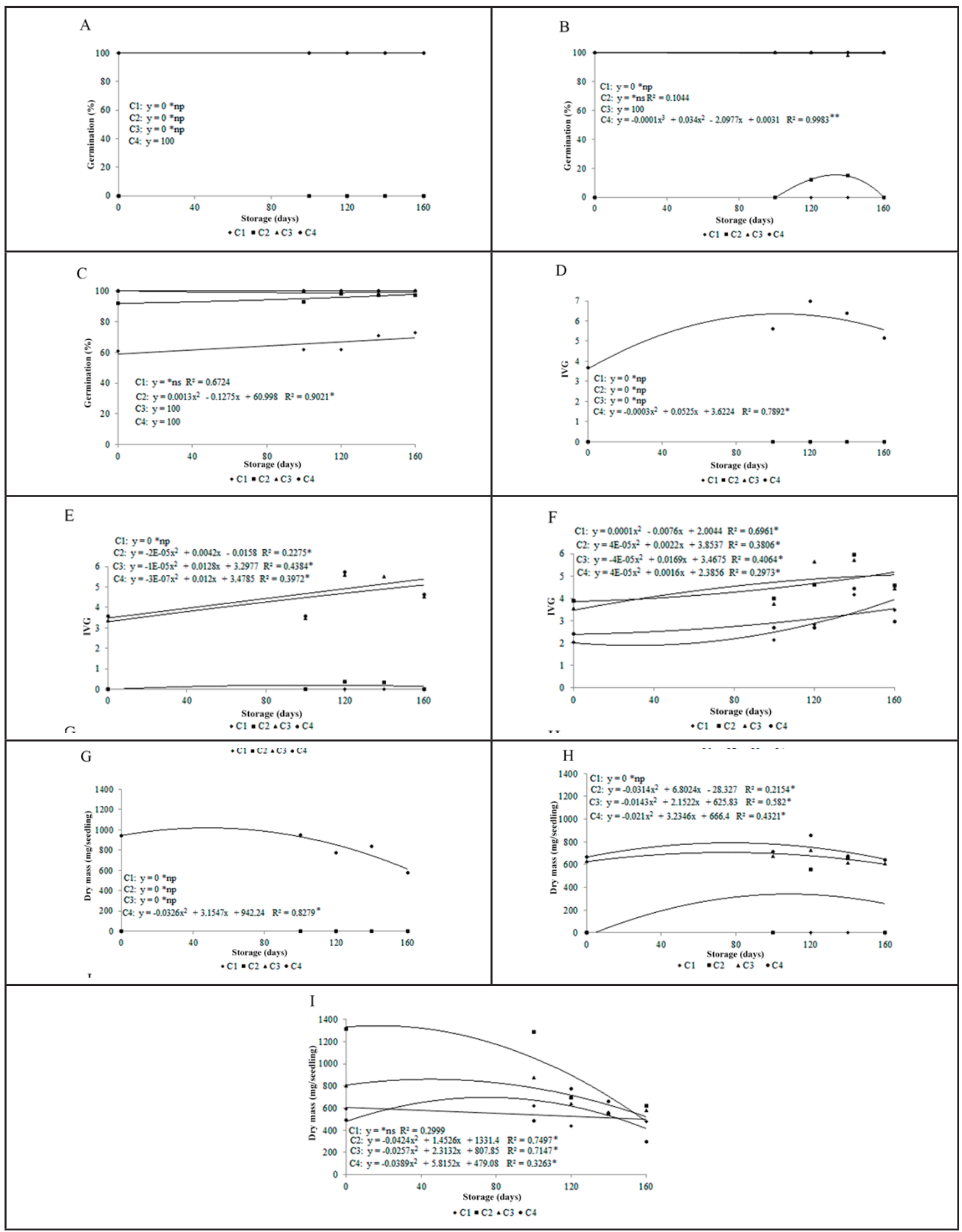

Figure 1. Germination (\%), speed germination index (IVG), and dry mass (mg per seedling) of the scarlet eggplant seedlings in soil with correctives and organic matter sources. Pure soil (A, D and G), sewage sludge (B, E and H), cattle manure (C, F and I); without correction (C1), limestone (C2), steel slag (C3), and marble powder (C4); *np No fruit production was noticed; *ns No significant; * Significant at $5 \%$ level; ** Significant at 1\% level. Alegre, UFES, 2016. 
energy reserves in the seeds. Lipids are considered as the major source of energy for germination and they can also have reserve and structural functions. Thus, the organization of lipoprotein membranes directly affects the normality of the physiological processes in seeds (Marcos Filho, 2005). During storage, seeds deteriorate mainly due to lipid peroxidation which causes disintegration of the membranes (Inayat-Ur-Rahman et al., 2013). However, Pukacka \& Rajajczak (2005) reported that the activation of antioxidant enzymes reduces the level of membrane lipid peroxidation and, consequently, reduces seed deterioration during storage.

Thus, such as germination percentage, the use of steel slag and marble powder stood out with high averages for variables: speed of germination and dry mass (Figure 1D, E, F, G, H and I). The highest averages for speed of germination and dry mass of seedlings from stored seeds were obtained in seeds produced in soils with organic source addition, highlighting those in which the authors used cattle manure, which averages were higher than sewage sludge (Figure 1D, E, F, G, H and I). The authors could observe, in all treatments, an increase in the rate of germination when the seeds were stored from 120 to 140 days, and a reduction after 160 days of storage (Figure 1D, E and F). Seed longevity varies according to the genotype, but the storage period of the physiological potential depends largely on the degree of humidity and the conditions of the storage environment (Marcos Filho, 2005; Abud et al., 2012). These results are not in agreement with the ones found by Zamariola et al. (2014) and Lima \& Schmiderle (2014), who evaluated vigor of eggplant and chilli pepper "Malagueta" seeds, respectively. The mentioned authors observed that after 90 days of storage, seed quality was affected negatively, showing reduction in germination and vigor.

According to the results obtained in these studies, steel slag and marble powder showed more potential for soil correction when comparing to limestone; sewage sludge and cattle manure are viable alternatives to fertilize soil for producing scarlet eggplant seeds. After 140 days of storage, the authors noticed negative effects on the seed vigor.

\section{ACKNOWLEDGEMENTS}

To CPNQ for the granting of productivity scholarship for the first and fifth authors.

\section{REFERENCES}

ABUD, HF; GONÇALVES, NR; PEREIRA, MS; PEREIRA, DS; REIS, RGE; BEZERRA, AME. 2012. Germination and morphological characterization of the fruits, seeds and seedlings of Pilosocereus gounellei. Brazilian Journal of Botany 35: 11-16.

BEWLEY, JD; BRADFORD, K; HILHORST, H; NONOGAKI, H. 2013. Seeds: physiology of development, germination and dormancy. 3 . ed., New York: Springer. 392p.

BRASIL. Ministério da Agricultura, Pecuária e Abastecimento. 2009. Regras para análise de sementes. Brasília: MAPA/ACS. 399p.

CALDEIRA, MVW; DELARMELINA, WM; PERONI, L; GONÇALVES, EO; SILVA, AG. 2013. Lodo de esgoto e vermiculita na produção de mudas de eucalipto. Pesquisa Agropecuária Tropical 43: 155-163.

CARVALHO, NM; NAKAGAWA, J. 2012. Sementes: ciência, tecnologia e produção. 5 . ed. Jaboticabal: FUNEP. 590p.

CARVALHO, TC; D’ANGELO, JWO; SCARIOT, GN; SALES JÚNIOR, LA; CUQUEL, FL. 2014. Germinação de sementes de Physalis angulata L.: estádio de maturação do cálice e forma de armazenamento. Pesquisa Agropecuária Tropical 44: 357-362.

CONAMA - Conselho Nacional Do Meio Ambiente. 2006, 19 de novembro. Resolução Conama $N^{o} 375$, de 29 de agosto de 2006. Disponível em www.mma.conama.gov.br/ conama.

EMBRAPA, 2004. Características de corretivos agrícolas. Documento 37. São Carlos: Pecuária Sudeste. 28p. (Embrapa Pecuária Sudeste. Documentos, 37).

FILGUEIRA, FAR. 2013. Novo manual de olericultura: agrotecnologia moderna na produção e comercialização de hortaliças, 3 . ed., Viçosa: Editora UFV. 421 p.

FREIRE, JC; RIBEIRO, MAV; BAHIA, VG; LOPES, AS; AQUINO, LH. 1980. Resposta do milho cultivado em casa de vegetação a níveis de água em solos da região de Lavras (MG). Revista Brasileira de Ciência do Solo 4: 5-8.

FREITAS, AR; LOPES, JC; ALEXANDRE, RS; VENANCIO, LP; ZANOTTI, RF. 2015. Emergência e crescimento de mudas de maracujá doce em função de lodo de esgoto e luz. Comunicata Scientiae 6: 234-240.

GROTTO, D; CARNEIRO, MFH; SAUER, E; BARBOSA, F. 2013. Evaluation of biochemical and redox parameters in rats fed with corn grown in soil amended with urban sewage sludge. Ecotoxicology and Environmental Safety 3: 188-194.

HEHENBERGER, E; KRADOLFER, D; KÖHLER, C. 2012. Endosperm cellularization defines an important developmental transition for embryo development. Development 139: 2031-2039.

INAYAT-UR-RAHMAN; ALI, N; RAB, A; SHAH, Z. 2013. Role of pre storage seed priming in controlling seed deterioration during storage. Sarhad Journal of Agriculture 29: 379-386.

INMET. 2015. Agrometeorologia. Disponível em http://www.inmet.gov.br/html/agro.html.

LEPRINCE, O; BUITINK, J. 2010. Desiccation tolerance: From genomics to the field. Plant Science 179: 554-564.

LIMA, JME; SCHMIDERLE, OJ. 2014. Qualidade fisiológica de sementes de pimenta obtidas em frutos de diferentes maturações e armazenadas. Semina: Ciências Agrárias 35: 251-258.

MACHADO, RV; RIBEIRO, RC; ANDRADE, FV; PASSOS, RR; MESQUITA, LF. 2010. Utilização de resíduos oriundos do corte de rochas ornamentais na correção da acidez e adubação de solos. Rio de Janeiro: CETEM/ MCT. 50 p. (Série Tecnologia Ambiental, 55).

MAGUIRE, JD. 1962. Speed of germinationaid in selection and evaluation for seedling emergence and vigor. Crop Science 2: 176177.

MARCOS FILHO, J. 2005. Fisiologia de sementes de plantas cultivadas. Piracicaba: FEALQ. 495p.

MARCOSFILHO, J. 1999. Teste de envelhecimento acelerado. In: KRZYZANOWSKI, FC; VIEIRA, RD; FRANÇA-NETO, JB (eds). Vigor de sementes: conceitos e testes. Londrina: ABRATES. p.1-24.

NASCIMENTO, WM. 2009. Tecnologia de sementes de hortaliças. Brasília: Embrapa Hortaliças. 432p.

NOGUEIRA, NO; MARTINS, LD; TOMAZ, MA; ANDRADE, FV; PASSOS, RR. 2013. Teor de nitrogênio, clorofila e relação clorofilacarotenoide em café arábica em solo submetido a diferentes corretivos de acidez. Revista Brasileira de Ciências Agrárias 8: 390-395.

OLIVEIRA, AP; SILVA, OPR; BANDEIRA, NV; SILVA, DF; SILVA, JA; PINHEIRO, SMG. 2014. Rendimento de maxixe em solo arenoso em função de doses de esterco bovino e biofertilizante. Revista Brasileira de Engenharia Agrícola e Ambiental 18: 1130-1135.

PREZOTTI, LC; GOMES, JA; DADALTO, GG; OLIVEIRA, JA. 2007. Manual de recomendação de calagem e adubação para o estado do Espirito Santo. 5 ed. Vitória: SEEA/ INCAPER/CEDAGRO. 305p.

PUKACKA, S; RATAJCZAK, E. 2005. Production and scavenging of reactive oxygen species in Fagus sylvatica seeds during storage at varied temperature and humidity. Journal of Plant Physiology 162: 873-85.

SILVA, EAS; CASSIOLATO, AMR; MALTONI, KL; SCABORA, MH. 2008. Efeitos da rochagem e de resíduos orgânicos sobre 
aspectos químicos e microbiológicos de um subsolo exposto e sobre o crescimento de Astronium fraxinifolium Schott. Revista Árvore 32: 323-333.

SILVA, PP; BARROS, ACSA; PINHO, EVRV; NASCIMENTO, WM. 2015. Physiological analysis and heat-resistant protein (LEA) activity in squash hybrid seeds during development. Journal of Seed Science 37: 185-191.
SOUZA, MO; SOUZA, CLM; BARROSO, NS; PELACANI, C. 2014. Preconditioning of Physalis angulata $\mathrm{L}$. to maintain the viability of seeds. Acta Amazonica 44: 153-156.

TAIZ, L; ZEIGER, E. 2013. Fisiologia vegetal. 5. ed. Porto Alegre: ARTMED. 954p.

TUNES, LM; TAVARES, LC; MENEGHELLO, GE; FONSECA, DAR; BARROS, ACSA; RUFINO, CA. 2013. Ácidos orgânicos na qualidade fisiológica de sementes de arroz. Ciência Rural 43: 1182-1188.

ZAMARIOLA, N; OLIVEIRA, JA; GOMES, LAA; JÁCOME, MF; REIS, LV. 2014. Effect of drying, pelliculation and storage on the physiological quality of eggplant seeds. Journal of Seed Science 36: 240-245. 